\title{
The Potential Role Of Sphingomonas paucimobilis In Bioremediation Of Soils Contaminated With Hydrocarbon And Heavy Metal
}

\author{
Raghad Shubbar Jaafar ${ }^{1 a^{*}}$ \\ ${ }^{a}$ Marine Science Center, University of Basra, Basra, IRAQ. Email: shubbarraghad @ gmail.com ${ }^{1}$ \\ *Corresponding author: shubbarraghad@gmail.com \\ Received: $1^{\text {st }}$ August $2019 \quad$ Accepted: $17^{\text {th }}$ October $2019 \quad$ Published: $31^{\text {st }}$ December 2019 \\ DOI: https://doi.org/10.22452/mjs.vol38no3.5
}

\begin{abstract}
Aiming to find the solution to the problem of soil polluted by hydrocarbons and the associated heavy metals, the present study focused on the biodegradation and bioremediation capability of Sphingomonas paucimobilis. Morphological and biochemical tests have been used to identify bacterial isolates and to confirm that an automated instrument for bacterial identification (Vitek II) has been used. Based on the results, the bacteria were identified as Sphingomonas paucimobilis. The bioremediation capacity was monitored: the lowest inhibitory concentration (MIC) of lead $(\mathrm{Pb})$ and cadmium $(\mathrm{Cd})$ followed by an assay of the removal capacity of $S$. paucimobilis using the atomic absorption spectrometry (AAS) analyzer. The bacteria showed higher MIC value for $\mathrm{Pb}(2000 \mathrm{ppm})$ the $\mathrm{Cd}(500 \mathrm{ppm})$. The percentage of removal for $\mathrm{Pb}$ and $\mathrm{Cd}$ were $27.95 \%$ and $58.78 \%$, and $22.37 \%$ and $48.21 \%$ for the concentration $25 \mathrm{ppm}$ and $50 \mathrm{ppm}$, respectively. These findings showed the high aliphatic hydrocarbon biodegradation capacity of $S$. paucimobilis, with the percentage of degradation being $48.15 \%$ and $63.40 \%$ of the concentration of crude oil by $2 \%$ and $5 \%$, respectively. S. paucimobilis can potentially be a safe biological treatment strategy to remediate soil polluted with hydrocarbons in crude oil extraction sites.
\end{abstract}

Key words: Sphingomonas paucimobilis, Bioremediation, Heavy Metal, Biodegradation, Hydrocarbons

\section{INTRODUCTION}

The decades-long extraction of oil from the south of Iraq, particularly in the Basra city led to significant damage to the environment, particularly the soil, as a result of the leakage of an enormous quantity of crude oil and associated pollutants, including heavy metals. The cumulative effect of organic and metallic pollutants on soil biology is more poisonous than that of hydrocarbons alone (Thavamani, 2012 ; Liu et al., 2013). The carcinogenic and mutagenic properties of both hydrocarbons and heavy metals have prompted researchers to study their combined effect on the environment (Lovelace et al., 2012).

Therefore, it is important to search for a solution to preserve the environment, taking into account that the required solution must be environmentally friendly. Bioremediation is a biological technique to recycle pollutants in a way that other 
organisms can use and reuse. Recently, there has been great attention towards bioremediation by using of bacteria to treat and eliminate the pollutants from the environment. Bacteria are effective tools for decontamination of soil, water and sediments. Thus, the key for bioremediation is the selection of efficient and proliferative bacteria (Zheng, 2016). Past research has indicated that hydrocarbon-degrading bacteria mostly belong to the Mycobacterium,Sphingomonas, Pseudomons, Bacillus, and Cycloclasticus clade (Yao, 2015). Therefore, the objectives of this study were to isolate and identify Sphingomonas from soils contaminated with hydrocarbons and examine their capacity to treat soil contaminated with hydrocarbons and the associated heavy metal.

\section{METHODS}

\subsection{Collection of Samples}

A total of thirty soil samples was collected in up to $20 \mathrm{~cm}$ depth from two different selected stations in the North Rumaila oil field in the Basra city south of Iraq during January 2018. The samples were labeled and stored in plastic bags. Each sample was separately air-dried, milled using porcelain pestle and mortar, and then sieved using a $2 \mathrm{~mm}$ sieve. The fine soil fractions were collected in separate bags and stored in a dry place for further analysis.

\subsection{Isolation and identification of bacteria}

Mineral Salts (MSM) supplemented with different concentration of crude oil have been used to isolate bacteria from soil samples. Mineral salt media with oil as the sole carbon source has been used to maintain bacteria. The MSM composition was as follows: $0.3 \mathrm{~g}$ of $\mathrm{KCl}, 1.0 \mathrm{~g}$ of K2HPO4, $0.5 \mathrm{~g}$ of KH2PO4, $0.01 \mathrm{~g}$ of FeSO4.7H2O, $30.0 \mathrm{~g}$ of $\mathrm{NaCl}, 0.5 \mathrm{~g}$ of $\mathrm{MnSO} 4.7 \mathrm{H} 2 \mathrm{O}, 0.2 \mathrm{~g}$ of $\mathrm{CaCl} 2$ and $1000 \mathrm{ml}$ DW (Fujisawa , 1980). The $\mathrm{pH}$ was adjusted to $7.0-7.8$.

Two concentrations of crude oil ( $2 \%$ and 5\%) obtained from the Al - Shua'aba Refinery was added separately to the medium. The culture was cultivated at $30^{\circ} \mathrm{C}$ for seven days. Nutrient agar (Hi mediaIndia) was used to isolate Sphingomonas paucimobilis. It was identified by morphological and biochemical tests, and for better identification, the automated instrument for bacterial identification (Vitek II) (Biomerieux, USA) was used.

\section{Heavy Metal Tolerance Assays}

\subsection{Preparation of the heavy metal concentrations}

Stock solutions of the metal salts were made by dissolving the exact weight of $\mathrm{Pb}(\mathrm{NO} 3) 2$ and $\mathrm{Cd}(\mathrm{NO} 3) 2 . \mathrm{H} 2 \mathrm{O}$ in sterile deionized water. The working concentration of the $\mathrm{Cd}$ (II) and $\mathrm{Pb}$ (II) was prepared from the stock solution according to Etorki et al. (2014).

\subsection{Tolerance determination}

This test was carried out to assess the heavy metal tolerance of the isolated bacteria. The isolates were grown in nutrient, heavy metal-free broth (NB, Hi media) at $25^{\circ} \mathrm{C}$ for $24 \mathrm{hr}$. After incubation, a loopful was taken from the culture and then aseptically cultured on nutrient agar containing $\mathrm{Cd}$ and $\mathrm{Pb}$, at different 
concentrations $(25,50,100,250,500,1000$, $1500,1800$ and $2000 \mathrm{ppm})$. The plates were incubated at $25^{\circ} \mathrm{C}$ for $48 \mathrm{hr}$. The minimal concentration of $\mathrm{Cd}$ and $\mathrm{Pb}$ that inhibited the growth was considered as the tolerance level. The test was repeated in triplicate and one control (Huët \& Puchooa, 2017).

\subsection{Estimation of the bacterium's capability to remove heavy metal}

Bacteria were cultured in $10 \mathrm{ml}$ of NB broth for one day at room temperature and $2 \mathrm{ml}$ of the suspension was injected in $\mathrm{NB}$ broth containing 25 and $50 \mathrm{mg} / \mathrm{l}$ of $\mathrm{Pb}$ and $\mathrm{Cd}$, respectively and incubated at $25^{\circ} \mathrm{C}$ for $24 \mathrm{hr}$. Then, the culture was centrifuged at $3000 \mathrm{rpm}$ for 20 minutes and the supernatant was collected and examined to assess the $\mathrm{Pb}$ and $\mathrm{Cd}$ removal by using the flame atomic absorption spectrophotometer (AAS 6300, Shimadzu, Japan). The step was performed in triplicates. The equation below was used to calculate the percentage of removal:

$\%$ elimination $=$ (reduction in heavy metal concentration $\div$ Initial heavy metal concentration) $\times 100$ (Huët \& Puchooa, 2017).

\subsection{Estimation of the oil degradation capability}

Erlenmeyer flask containing $50 \mathrm{ml}$ of MSM supplemented with $1 \mathrm{~mL}$ bacterial culture was incubated in an incubator shaker at $20^{\circ} \mathrm{C}$ for 7 days at $120 \mathrm{rpm}$. The remaining crude oil was measured after one week and the test was carried out in duplicates (Alkanany et al., 2017).

\subsection{Extraction of crude oil residues}

The procedure outlined by Adebusoye et al. (2007) was used to extract the residual crude oil from the MSM medium. The extraction procedure included adding $50 \mathrm{ml}$ of carbon tetrachloride $(\mathrm{CCl} 4)$ solvent to the bacterial culture. This is commonly used to extract all hydrocarbons and inhibit bacterial growth and activity (Aizenman, 1989). The addition was performed during the step of continuous shaking. The culture was transferred to a separating funnel and allowed to settle. The suspension was removed, and the remaining oil was dried in an oven at $40^{\circ} \mathrm{C}$ to get rid of $\mathrm{CCl} 4$.

Extraction of aliphatic fraction was done according to Farid (2006). The procedure included adding $35 \mathrm{ml}$ of hexane to the remaining pre-extracted crude oil and pouring that entire solvent into a column closed with glass wool and topped with $8 \mathrm{~g}$ of silica gel. The remaining pre-extracted crude oil and solvent passed through the column after which Hexane aliphatic fraction was collected in $50 \mathrm{ml}$ beaker and the remaining extract was left to dry completely; another $2 \mathrm{~mL}$ of hexane was added to the beaker before measured using gas chromatography.

\section{RESULTS AND DISCUSSION}

\subsection{Identification of Sphingomonas Paucimobilis}

The isolated bacteria were identified based on their morphology and biochemical 
test (Table1). For further identification, an automated instrument for bacterial identification (Vitek II, C8300 Biomerieux
USA) was used. The result was within $95 \%$ confidence.

Table 1. Morphological and biochemical characteristics of S. Paucimobilis

\begin{tabular}{cc}
\hline Colony Morphology & Results \\
\hline Cell shape & Rod shape \\
Motility & Motile \\
Pigment & Yellow color colony \\
Gram reaction & - \\
\hline H2S formation & Biochemical Tests \\
Catalase & - \\
Nitrate reduction & + \\
Urease & - \\
Oxidase & + \\
Glucose & + \\
Sucrose & - \\
Simon citrate & - \\
& + \\
\hline
\end{tabular}

\subsection{Metal Resistant Pattern}

The MIC is defined as the lowest concentration of metals that inhibits bacterial growth (Yilmaz., 2003). The MIC is considered as an initial step to evaluate the susceptibility or tolerance of bacteria towards the remediation of heavy metal. Table 2 shows the MIC results; the bacterial isolates were resistant to high concentrations of $\mathrm{Pb}(2000 \mathrm{ppm})$ and $\mathrm{Cd}(500 \mathrm{ppm})$. The low MIC values showed the most toxic metals while the maximum MIC values indicated the least toxic ones (Mishra \& Mishra, 2015).

Tangaromsuk et al. (2002) reported high tolerance of $S$. paucimobilis to the $\mathrm{Cd}$. They found that the bacteria were capable of living in the concentration of cadmium higher than $200 \mathrm{mg} / \mathrm{l}$. However, their resistance to $\mathrm{Pb}$ was higher than that to $\mathrm{Cd}$. This is because, there is a high rate of lead in the environment compared to cadmium, leading to an increased resistance of the bacteria as a means of survival (Habi \& Daba, 2009). A pollution with a particular metal can raise the level of tolerance of the bacterial community towards that metal (Mishra \& Mishra, 2015). Other studies showed that the concentrations of metals as well as many physical and chemical factors played a prominent role in increasing the susceptibility of bacteria to different concentrations of metals (Afzal et al., 2017).

The results of this bioremediation study using two concentrations (25 and 50 ppm) from $\mathrm{Pb}$ and $\mathrm{Cd}$ are shown in Table 2 and Figure 1, indicating that $S$. paucimobilis was capable to eliminate $\mathrm{Pb}$ and $\mathrm{Cd}$, with the percentage of $\mathrm{Pb}$ removal being 27.95 and $58.78 \%$ in the concentration of 25 and $50 \mathrm{ppm}$, respectively. The removal of $\mathrm{Pb}$ was concentration-dependent; as the concentration increased the percentage of 
removal increased. The result of $\mathrm{Cd}$ removal was 22.37 and $48.21 \%$ for 25 and $50 \mathrm{ppm}$, respectively. The manner of removal was same to that for $\mathrm{Pb}$. The result indicated that there was an increase in $\mathrm{Pb}$ and $\mathrm{Cd}$ removal as the concentration increased, indicating that the removal occurred in a diffuse manner. The higher the concentration, the greater the movement of molecules or ions (Ahemad \& Malik, 2011).

There are also indications that the removal capacity of $S$. paucimobilis was higher for $\mathrm{Pb}$ than $\mathrm{Cd}$. Allam (2017) reported that the removal ability of $\mathrm{Pb}$ was higher than $\mathrm{Cd}$ (57 and 53\%).

Table 2. The minimum inhibitory concentration ( $\mathrm{ppm}$ ), and heavy metal removal.

\begin{tabular}{cccc}
\hline \multicolumn{4}{c}{ Heavy metals removal $(\%) / 24 \mathrm{~h}$} \\
\hline Heavy metals & MIC $(\mathrm{ppm})$ & $50 \mathrm{ppm}$ & $25 \mathrm{ppm}$ \\
$\mathrm{Pb}$ & 2000 & 58.78 & 27.95 \\
$\mathrm{Cd}$ & 500 & 48.21 & 22.37 \\
\hline
\end{tabular}

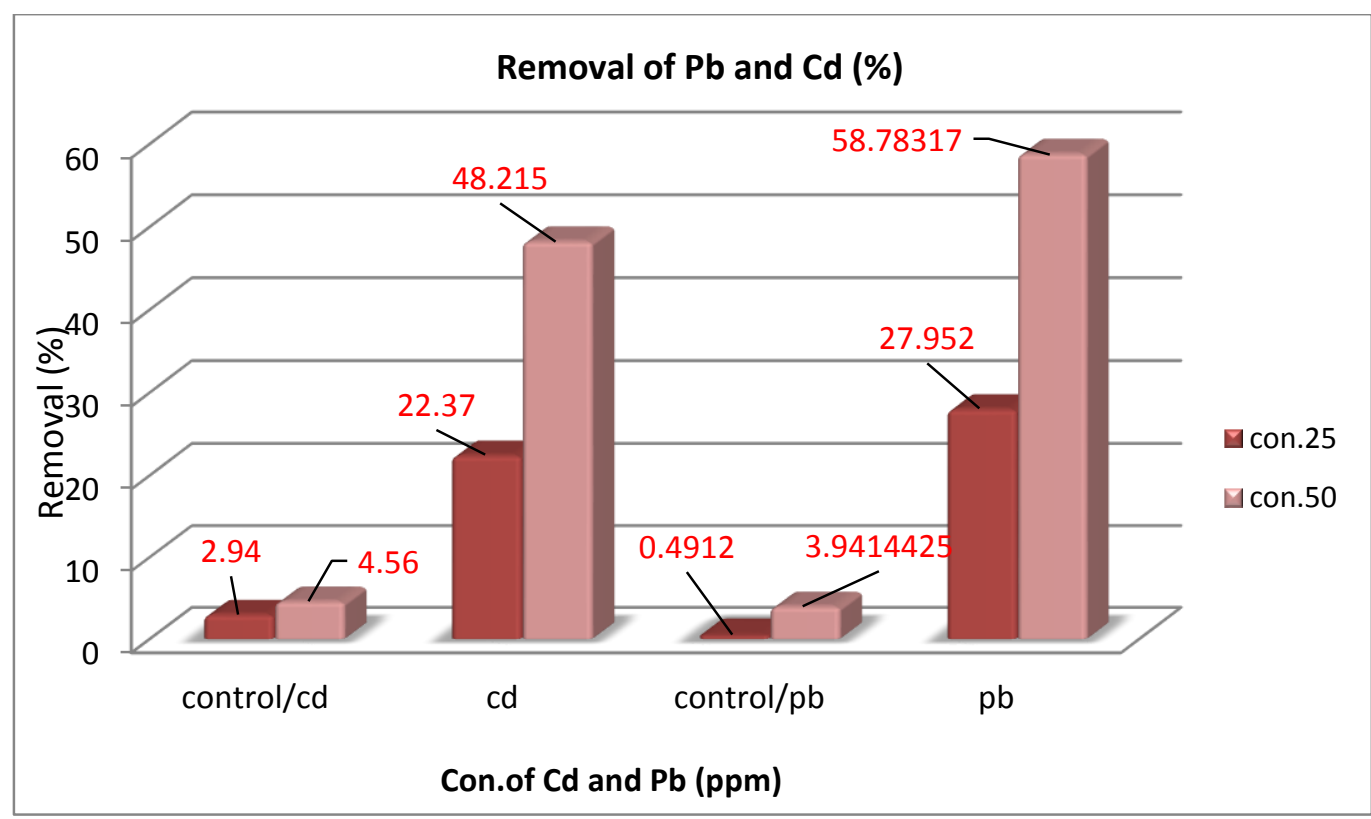

Figure 1. Removal of $\mathrm{Pb}$ and $\mathrm{Cd}(\%)$ by $\mathrm{S}$. Paucimobilis

\subsection{Degradation study}

To examine the ability of $S$. paucimobilis to degrade hydrocarbons (aliphatic part), GC-MS analysis of the control (only crude oil and without microorganisms) showed that it was a mixture of different aliphatic hydrocarbons at the different concentration of crude oil (5\% and 2\%) (Fig.2.A and Fig.3.A). S. paucimobilis was capable of actively degrading the total mixture of hydrocarbons present in the crude oil of two concentrations (5\% and 2\%) during the 
seven days of incubation. The result was confirmed by an almost total reduction of the amount of each compound peak (Fig.2.B and Fig.3.B).

Table 3 shows the percentage of oil degradation by $S$. paucimobilis. $S$. paucimobilis was more effective to degrade oil in $5 \%(63.40 \%)$ than $2 \%$ concentration (48.15). The ability of $S$. paucimobilis to degrade the aliphatic compound was also reported in previous work by Al-Taee et al. (2017) where they showed the percentage of removal of $67 \%$ for the $2 \%$ concentration of crude oil. Barth (2003) reported that Sphingomonas bacteria was typical in hydrocarbon degradation. Zhuang et al. (2003) referred to Sphingomonas as one of hydrocarbon degradation bacteria.

One of the factors that can play crucial roles in the ability of a bacterium to degrade hydrocarbons include the available concentration of hydrocarbons to the bacteria. The higher the available concentration of hydrocarbons, the higher the percentage of removal and the degree of interactions between bacteria and hydrocarbons required for the oxygenation process (Hua \& Wang, 2014).

Therefore, bacteria with the ability to remove high amounts of hydrocarbons seem to develop an adhesive ability through changing their surface component (Krasowska \& Sigler, 2014). The composition of hydrocarbons is considered as a vital factor as reported by Varjani (2017). Hydrocarbons can be arranged according to the degradation as follows: linear alkanes > branched alkanes > low molecular weight alkyl aromatics > monoaromatics > cyclic alkanes > polyaromatics $>$ asphaltenes.

The chemical and physical properties of substrate materials as well as their bioavailability affect the ability of bacteria to contact, transport, and convert hydrocarbons (Varjani \& Upasani, 2017).

Table 2. Degradation percentage of crude oil

\begin{tabular}{ccc}
\hline & S. Paucimobilis & \\
\hline Concentration/ 2\% & Concentration/ 5\% \\
$48.15 \%$ & $63.40 \%$ \\
\hline
\end{tabular}




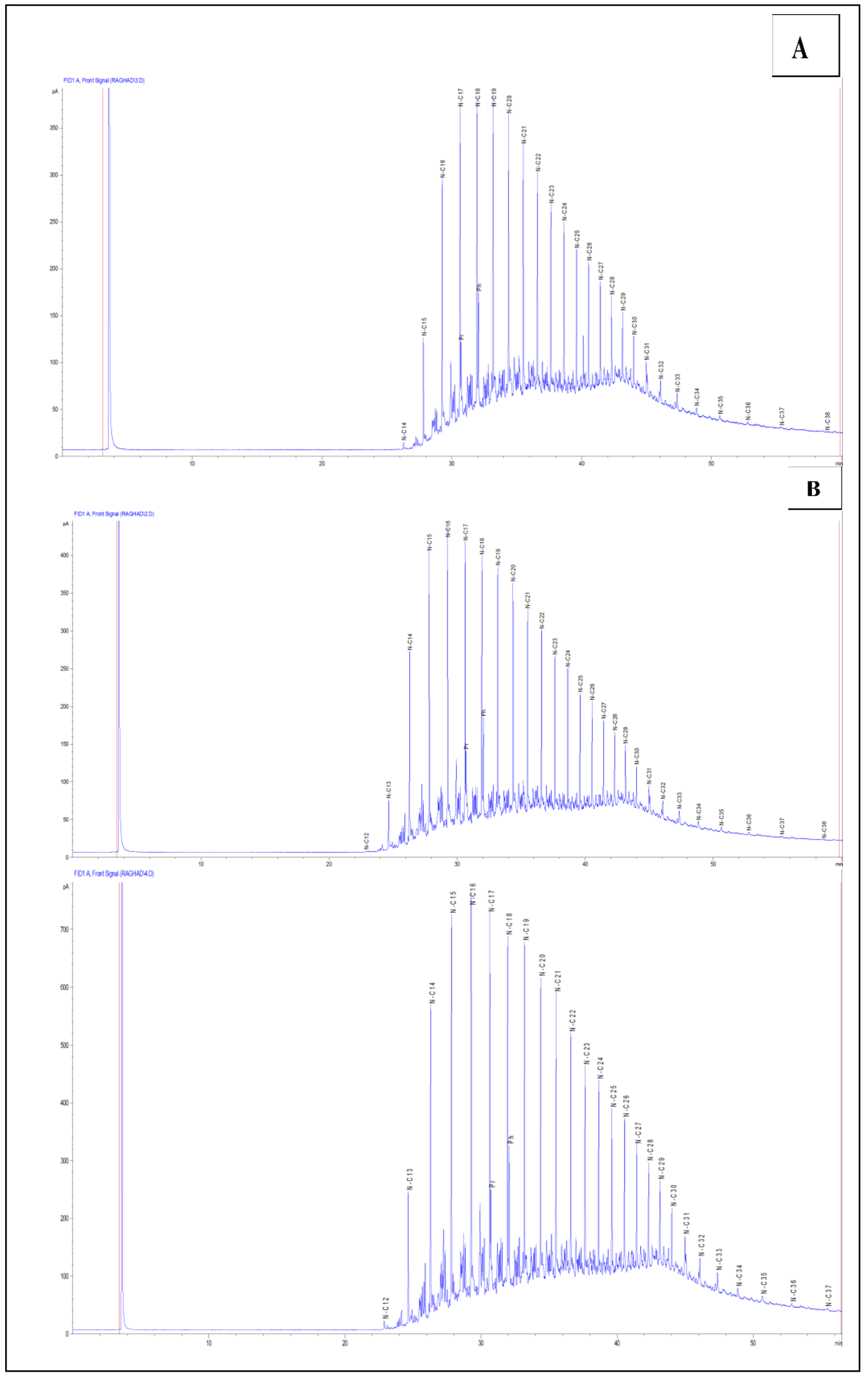

Figure 2. A: Crude oil (aliphatic fraction, 5\%) without; bacteria and B: Crude oil (5\%) with S. Paucimobilis 


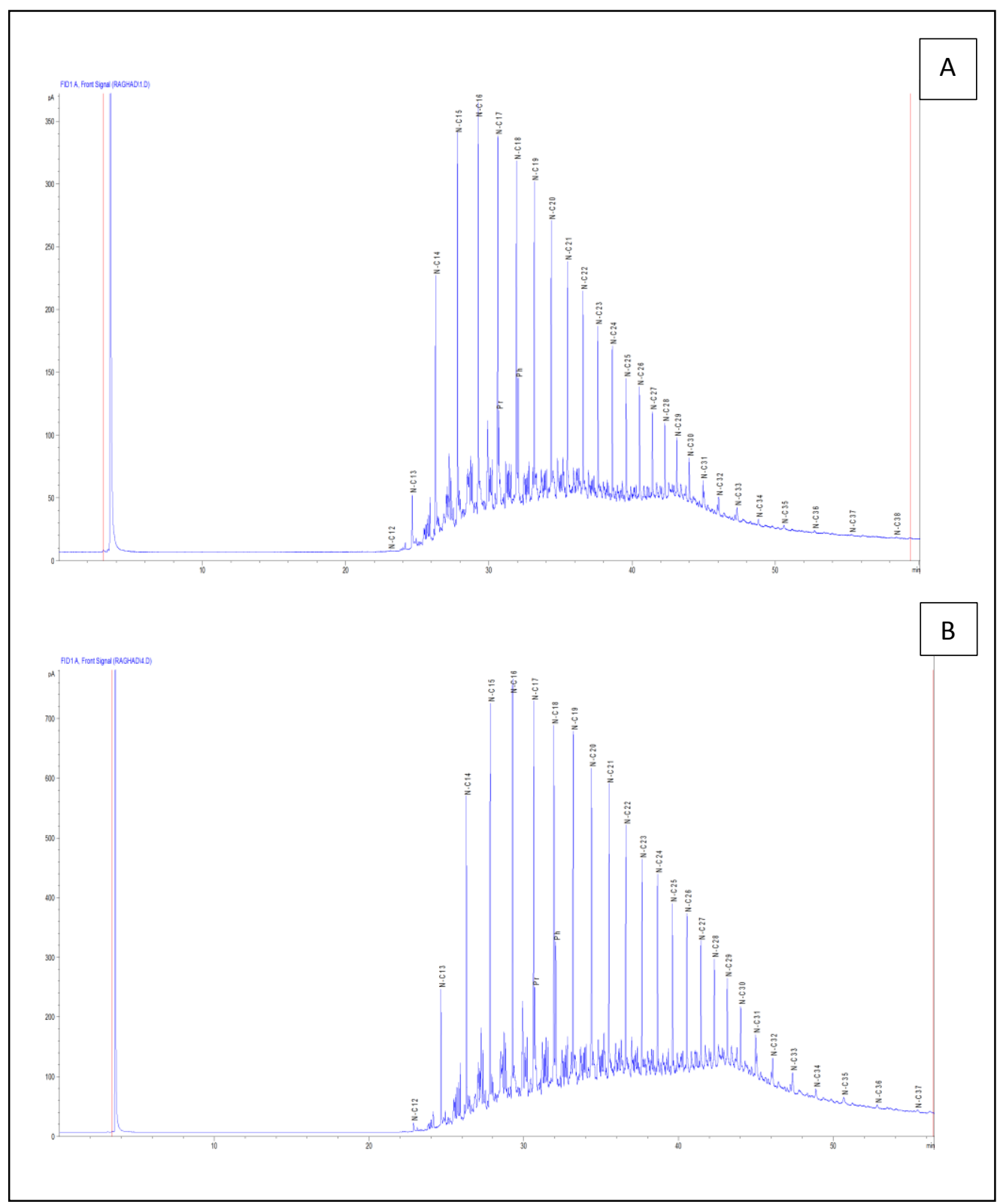

Figure 3. A: Crude oil (aliphatic fraction, 2\%) without; bacteria and B: Crude oil (2\%) with S. Paucimobilis

\section{CONCLUSIONS}

Based on these findings, $S$. paucimobilis is considered as an excellent agent in bioremediating soil polluted with both hydrocarbons and associated heavy metal since the isolated organism showed perfect tolerance and removal capacity. The possibility of isolating these bacteria from the soil is a good indicator for the healthy state of the soil, meaning that the soil is capable of self-treatment. Therefore, in order to improve this possibility, reviving these bacteria is important to increase their 
efficiency and potential in soil bioremediation as a safe and environmentally friendly treatment.

\section{FUTURE RECOMMENDATION}

These bacteria can be used in-situ bioremediation after increasing its biomass construction in a large-scale bioreactor. Further research is needed to uncover the bacterial capacity to perform bioremediation of other heavy metals that cause environmental pollution. Finally, it is important to search for the genes responsible for the bioremediation to develop recombinant strains.

\section{ACKNOWLEDGMENTS}

I would like to thank the lab of marine bacteriology, Marine science center, The University of Basra for all the facilities provided and supports.

\section{REFERENCES}

Abatenh E, G. B., Tsegaye Z, Wassie M (2017). The Role of Microorganisms in Bioremediation- A Review. Open Journal of Environmental Biology, 2 (1), 038-046. .

Adebusoye, S. A., Ilori, M. O., Amund, O. O., Teniola, O. D., \& Olatope, S. (2007). Microbial degradation of petroleum hydrocarbons in a polluted tropical stream. World journal of Microbiology and Biotechnology, 23(8), 1149-1159.
Afzal, A. M., Rasool, M. H., Waseem, M., \& Aslam, B. (2017). Assessment of heavy metal tolerance and biosorptive potential of Klebsiella variicola isolated from industrial effluents. AMB Express, 7(184), 2-9.

Ahemad, M., \& Malik, A. (2011). Bioaccumulation of heavy metals by zinc resistant bacteria isolated from agricultural soils irrigated with wastewater. Bacteriol. J, 2, 12-21.

Aizenman, E., Lipton, S. A., \& Loring, R. H. (1989). Selective modulation of NMDA responses by reduction and oxidation. Neuron, 2 (3), 1257-1263.

Al-Taee, A. M., Alkanany, N., Gmais, S. A., \& Alshawi, H. A. (2017). Biodegradation of Aliphatic Hydrocarbons by Bacteria Isolated from Khor Al-Zubair Channel, Southern Iraq. International Journal of Marine Science, 7(18), 176-182.

Alkanany, F. N., Gmais, S. A., Maki, A. A., \& Altaee, A. M. (2017). Estimation of Bacterial Biodegradability of PAH in Khor Al-Zubair Channel, Southern Iraq. International Journal of Marine Science, 7(42), 399-410.

Allam, N. G. (2017). Bioremediation Efficiency of Heavy Metals and Azo Dyes by Individual or Consortium Bacterial Species Either as Free or Immobilized Cells: A Comparative Study. Egyptian journal of botany, 57(3), 555-564.

Barth, H.-J. (2003). The influence of cyanobacteria on oil polluted intertidal soils at the Saudi Arabian 
Gulf shores. Marine pollution bulletin, 46(10), 1245-1252.

Etorki, A. M., El-Rais, M., Mahabbis, M. T., \& Moussa, N. M. (2014). Removal of some heavy metals from wastewater by using of fava beans. American Journal of Analytical Chemistry, 5(04), 225.

Farid, W. (2006). Effect of plant extracts on the microbial degradation of petroleum. Thesis of Phd. University of Basra, Iraq, college of education, 2006 149p.

Fujisawa H., a. M. M. (1980). Method for screening-oxidizing bacteria in the sea. $28,101-108$

Habi, S., \& Daba, H. (2009). Plasmid incidence, antibiotic and metal resistance among enterobacteriaceae isolated from Algerian streams. Pakistan Journal of Biological Sciences, 12(22), 1474.

Hua, F., \& Wang, H. Q. (2014). Uptake and trans-membrane transport of petroleum hydrocarbons by microorganisms. Biotechnology \& Biotechnological Equipment, 28(2), 165-175.

Huët, M. A. L., \& Puchooa, D. (2017). Bioremediation of heavy metals from aquatic environment through microbial processes: A potential role for probiotics? Journal of Applied Biology \& Biotechnology Vol, 5(6), 14-23.

Krasowska, A., \& Sigler, K. (2014). How microorganisms use hydrophobicity and what does this mean for human needs? Frontiers in cellular and infection microbiology, 4, 112.

Liu, M., Huang, B., Bi, X., Ren, Z., Sheng, G., \& Fu, J. (2013). Heavy metals and organic compounds contamination in soil from an ewaste region in South China. Environmental Science: Processes \& Impacts, 15(5), 919-929.

Lovelace, S., Goedeke, T. L., \& Dillard, M. K. (2012). Prioritizing county-level indicators of human well-being moving toward assessment of Gulf Coast counties impacted by the Deep Water Horizon industrial disaster.

Mishra, A., \& Mishra, K. P. (2015). Bacterial response as determinant of oxidative stress by heavy metals and antibiotic. J Innov Pharm Biol Sci, 2(3), 229-239.

Tangaromsuk, J., Pokethitiyook, P., Kruatrachue, M., \& Upatham, E. (2002). Cadmium biosorption by Sphingomonas paucimobilis biomass. Bioresource Technology, 85(1), 103-105.

Thavamani, P. M., S. ; Beer, M. ; Megharaj, M. and Naidu, R. (2012). Microbial activity and diversity in long-term mixed contaminated soils with respect to polyaromatic hydrocarbons and heavy metals. Journal of environmental management, 99, 1017.

Varjani, S. J. (2017). Microbial degradation of petroleum hydrocarbons. Bioresource Technology, 223, 277286. 
Varjani, S. J., \& Upasani, V. N. (2017). Critical review on biosurfactant analysis, purification and characterization using rhamnolipid as a model biosurfactant. Bioresource technology, 232, 389397.

Yao, L., Teng, Y., Luo, Y., Christie, P., Ma, W., Liu, F., ... \& Li, Z. (2015). Biodegradation of polycyclic aromatic hydrocarbons (PAHs) by Trichoderma reesei FS10-C and effect of bioaugmentation on an aged
PAH-contaminated

soil. Bioremediation Journal, 19(1), 9-17.

Yilmaz, E. I. (2003). Metal tolerance and biosorption capacity of Bacillus circulans strain EB1. Research in microbiology, 154(6), 409-415.

Zhuang, W. Q., Tay, J. H., Maszenan, A., Krumholz, L., \& Tay, S. L. (2003). Importance of Gram-positive naphthalene-degrading bacteria in oil-contaminated tropical marine sediments. Letters in applied microbiology, 36(4), 251-257. 